\title{
Participation of Acetolactate and Acetoin Producing System for Chlorsulfuron-Sensitivity in Higher Plants
}

\author{
Masanobu Nakata*
}

\begin{abstract}
The properties of acetolactate and acetoin producing systems were studied using several plant species at different growth stages. The effects of herbicide chlorsulfuron on the correlation between these systems and plant growth were investigated, and the methods for determining acetolactate formed during the enzyme assay were evaluated.
\end{abstract}

None of the plant species was inhibited in germination of seeds by chlorsulfuron. Growth and the acetolactate synthase (ALS) activity of rice and wheat were inhibited by chlorsulfuron, whereas growth of mungbean, soybean and azuki bean was not inhibited during the 4 days after germination. It was concluded that the chlorsulfuron-insensitivity of soybean depended on the contents of both ALS and acetoin forming enzyme: the content of ALS in soybean during the early days after germination was very low, whereas that of acetoin forming enzyme was very high. The enzyme which formed acetoin in soybean had optimum $\mathrm{pH}$ at 6 and this decreased with growth; ALS which had optimum $\mathrm{pH}$ at 7-8 began to increase from the 5 days after germination. The gas chromatographic method was used to determine acetolactate synthesized from pyruvate and acetohydroxybutyrate (AHB) synthesized from pyruvate and ketobutyrate during the enzyme assay. AHB synthesis in the enzyme assay was inhibited by chlorsulfuron at the same concentration as inhibited acetolactate synthesis. Acetolactate, acetoin and pyruvate were separated by high

* Laboratory of Pesticide Science, Faculty of Agriculture, Kobe University, Nada-ku, Kobe, 657, Japan (Received June 23, 1990) performance liquid chromatography using authentic compounds, but no acetolactate was present in a detectable amount in the enzyme reaction products.

Key words: acetolactate synthase, acetolactate, acetoin, chlorsulfuron.

\section{Introduction}

Enzyme acetolactate synthase (ALS) catalyzes synthesis of the branched-chain amino acids valine and leucine through production of 2-acetolactate from two molecules of pyruvate, and isoleucine by production of 2 -acetohydroxybutyrate from pyruvate and 2-ketobutyrate.

Studies on ALS have been conducted in bacteria, fungi and higher plants ${ }^{8,13,15,19)}$, however, detailed information on ALS is available only from the work on bacterial enzyme. Three major isozymes of ALS have been identified in Escherichia coli and Salmonella typhirimurim ${ }^{1,3,6)}$. They were found to be inhibited by three structurally unrelated classes of herbicides, sulfonylureas, imidazolinones and triazole pyrimidines ${ }^{5,9,16,17)}$. These isozymes are subject to feedback inhibition by valine. Isozymes II and III are subject to inhibition by sulfonylurea herbicides, whereas isozyme I is insensitive ${ }^{11)}$. Although higher plant ALS has been studied since these herbicides were developed, it has not yet been purified from higher plants. The difficulty in purification is due to its extremely low content in plant tissues and its instability. Recently, however, some partial purification of plant ALS has been made from maize ${ }^{14)}$ and barley ${ }^{4)}$. 
The enzyme activity was assayed on the basis of the condensation of two molecules of pyruvate. The product, acetolactate is measured by the amount of acetoin produced after acid decarboxylation of acetolactate. When the crude enzyme extracted from a plant is used for the assay of ALS activity, both acetolactate and acetoin are formed during the enzyme assay ${ }^{2,14)}$. The formation of acetoin varies with the plant species and growth stages. Acetolactate generally is measured by determining the amounts of acetoin converted from decarboxylation of acetolactate. Therefore, acetoin thus formed during the ALS assay interrupts the measurement of acetolactate. In this report, we studied the acetolactate and acetoin producing systems in several higher plants at different growth stages. We also studied the effect of sulfonylurea herbicide on germination and growth of the plants as well as ALS activity. In addition to the spectrophotometric method, other procedures available for determining acetolactate from ALS assay solution were evaluated.

\section{Materials and Methods}

\section{Plant Materials}

Soybean, azuki bean, mungbean, rice, wheat and barley were grown in a greenhouse at $25^{\circ} \mathrm{C}$. Radish (root) and leek (Chinese leek, Allium tuberosum R.) were purchased from a market.

\section{Chemicals}

Analytical grade chlorsulfuron was the generous gift of Du Pont Japan Company.

Inhibition test of germination and growth by chlorsulfuron

Ten seeds of each plant were placed in $9 \mathrm{~cm}$ petri dishes and $15 \mathrm{ml}$ of different concentrations of chlorsulfuron was added. The seeds were germinated and cultivated in a greenhouse at $25^{\circ} \mathrm{C}$. Growth inhibition was determined by weighing the fresh shoots and roots 4 days after germination.

\section{Extraction of ALS}

Extraction of ALS was carried out as de- scribed by $\mathrm{Ray}^{16)}$. Plant tissues were homogenized in 5 volumes of extraction buffer containing $0.1 \mathrm{M} \mathrm{K}$-phosphate (pH 7.5), $1 \mathrm{mM}$ sodium pyruvate, $0.5 \mathrm{mM} \mathrm{MgCl}_{2}, 0.5 \mathrm{mM}$ thiamine pyrophosphate (TPP), $10 \mu \mathrm{M}$ flavine adenosine dinucleotide (FAD) and 10\% (v/v) glycerol. The homogenate was centrifuged at $12,000 \mathrm{rpm}$ for $20 \mathrm{~min}$. The enzyme was collected at $20-50 \%$ saturation with ammonium sulfate by centrifugation at $10,000 \mathrm{rpm}$ for 15 min. After centrifugation, the pellet was dissolved in $20 \mathrm{mM} \mathrm{K}$-phosphate buffer ( $\mathrm{pH}$ 7.5) containing $0.5 \mathrm{mM} \mathrm{MgCl} 2$ and desalted on a column of Sephadex G-25 equilibrated with the same buffer.

\section{ALS assay}

The reaction mixture contained $20 \mathrm{mM} \mathrm{K}$ phosphate buffer ( $\mathrm{pH} 7.0$ ), $20 \mathrm{mM}$ sodium pyruvate, $0.5 \mathrm{mM}$ TPP, $0.5 \mathrm{mM} \mathrm{MgCl}_{2}$, and $10 \mu \mathrm{M} \mathrm{FAD}$ in a total volume of $0.5 \mathrm{ml}^{16)}$, and was incubated at $30^{\circ} \mathrm{C}$ for $1 \mathrm{hr}$. Acetolactate was measured by the following three methods.

(1) Spectrophotometric (SP) method:

The ALS activity was determined by measuring the amounts of acetoin converted by decarboxylation of acetolactate formed in the ALS assay. The measurement of acetoin was based on the Westerfeld test ${ }^{18)}$ for carbinols. After 1 hour of incubation, $50 \mu \mathrm{l}$ of $6 \mathrm{~N} \mathrm{H}_{2} \mathrm{SO}_{4}$ was added to stop the reaction and to convert acetolactate produced into acetoin at $60^{\circ} \mathrm{C}$ for 15 min. A color complex was formed during incubation of acetoin with creatine $(0.17 \%)$ and 1 -naphtol $(1.7 \%$ in $0.8 \mathrm{~N} \mathrm{NaOH})$ at $60^{\circ} \mathrm{C}$ for $15 \mathrm{~min}$, and the absorbance of the resultant color complex was measured at $525 \mathrm{~nm}$. The checks of direct acetoin formation during the enzyme assay were made using an undecarboxylated sample added with $50 \mu \mathrm{l}$ of $6 \mathrm{~N} \mathrm{NaOH}$ instead of $50 \mu \mathrm{l}$ of $\mathrm{H}_{2} \mathrm{SO}_{4}$ to the reaction mixture.

(2) Gas chromatographic (GC) method:

The enzyme reaction mixture was diluted 20 times with $\mathrm{FeCl}_{3}$ and $\mathrm{FeSO}_{4}$ solution (iron 
salt, final $0.15 \mathrm{mM}$ each). This solution was incubated in a large test tube $(30 \times 210 \mathrm{~mm})$, tightly sealed with a Teflon stopper, for $10 \mathrm{~min}$ at $80^{\circ} \mathrm{C}$, to convert acetolactate into diketone (2,3-butanedion). Diketone was distilled by air through the solution in a test tube held in a bath at $60^{\circ} \mathrm{C}$ and collected in a small tube containing $2 \mathrm{ml}$ of dry methyl alcohol on ice. Diketones were measured by the method of Gollop et al. ${ }^{7)}$. The methanol solution of diketone was analyzed by gas liquid chromatograph on a $3 \mathrm{~mm} \times 4.3 \mathrm{~m}$ column of $5 \%$ polyethyleneglycol $20 \mathrm{M}$ (Gaschrom Q) at $95^{\circ} \mathrm{C}$, with a flow rate of nitrogen of $1 \mathrm{~kg}$ / $\mathrm{cm}^{3}$. The injector and the detector were held at $140^{\circ} \mathrm{C}$. A Shimadzu Model GC-8 A gas chromatograph equipped with a ${ }^{63} \mathrm{Ni}$ electron capture detector was used.

(3) High performance liquid chromatographic (HPLC) method:

After incubation, $1 \mathrm{ml}$ of ethyl alcohol was added to the reaction mixture and centrifugated at $2,000 \mathrm{rpm}$ for $5 \mathrm{~min}$ to remove proteins. The supernatant was filtered through a membrane filter (pore size $0.22 \mathrm{~nm}$ ). Acetolactate was analyzed by HPLC on a $7.9 \mathrm{~mm} \times$ $30 \mathrm{~cm}$ column of Shimadzu Gel SCR-101 H (anion exchanger) maintained at $40^{\circ} \mathrm{C}$ in an oven. A perchloric acid solution ( $\mathrm{pH}$ 2.1) was used as a mobile phase. A Shimadzu LC-3 A HPLC was used and acetolactate was detected at $210 \mathrm{~nm}$ by ultraviolet detector.

\section{Synthesis of acetolactate}

Acetolactate was prepared by hydrolysis of ethyl-2-acetoxy-2-methyl acetoacetate (EAMA) by the method of Krampitz ${ }^{10)}$. Five hundred $\mathrm{mg}$ of EAMA was dissolved in $30 \mathrm{ml}$

Table 1. Effects of chlorsulfuron on germination of several plant seeds.

\begin{tabular}{ccccc}
\hline \multirow{2}{*}{$\begin{array}{c}\text { Chlorsulfuron } \\
(\mathrm{ppb})\end{array}$} & \multicolumn{3}{c}{ Germinated seeds (\% of control) } \\
\cline { 2 - 5 } & Mungbean & Soybean & Adzuki bean & Rice \\
\hline 0.5 & 105 & 89 & 100 & 90 \\
5 & 105 & 100 & 100 & 90 \\
50 & 105 & 111 & 100 & 95 \\
\hline
\end{tabular}

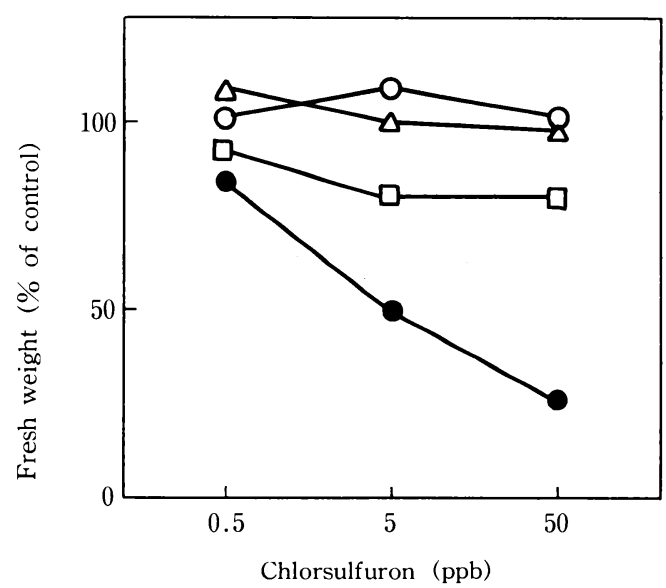

Fig. 1. Effects of chlorsulfuron on plant growth at 4 days after germination.

$-\mathrm{O}-$ : mungbean $-\triangle-$ : soybean

- $\square$-: adzuki bean - - - rice

of diethyl ether, to which $50 \mathrm{ml}$ of $50 \mathrm{mM}$ $\mathrm{NaOH}$ solution was added, by shaking a flask under nitrogen gas flow at room temperature. The water layer was adjusted by $\mathrm{NaOH}$ at $\mathrm{pH}$ 7 and washed twice with diethyl ether. The synthesized acetolactate was used as a water solution without further purification.

\section{Results}

\section{Chlorsulfuron inhibition test of germina-} tion and growth

The effects of chlorsulfuron on seed germination are shown in Table 1 and those on plant growth at 4 days after germination were shown in Fig. 1. At no concentration was germination of any of the seeds inhibited by cholrsulfuron. Growth of rice 4 days after germination was inhibited by $50 \%$ at $5 \mathrm{ppb}$ (14 nM) chlorsulfuron. However, growth of soybean and mungbean was not inhibited even by $50 \mathrm{ppb}$ chlorsulfuron.

\section{Chlorsulfuron inhibition of ALS activity} of soybean after germination

Since growth of soybean 4 days after germination was not inhibited by chlorsulfuron (Fig. 1), the effects of the herbicide on soybean ALS activity were tested at different growth stages. Soybean seeds were germinated 


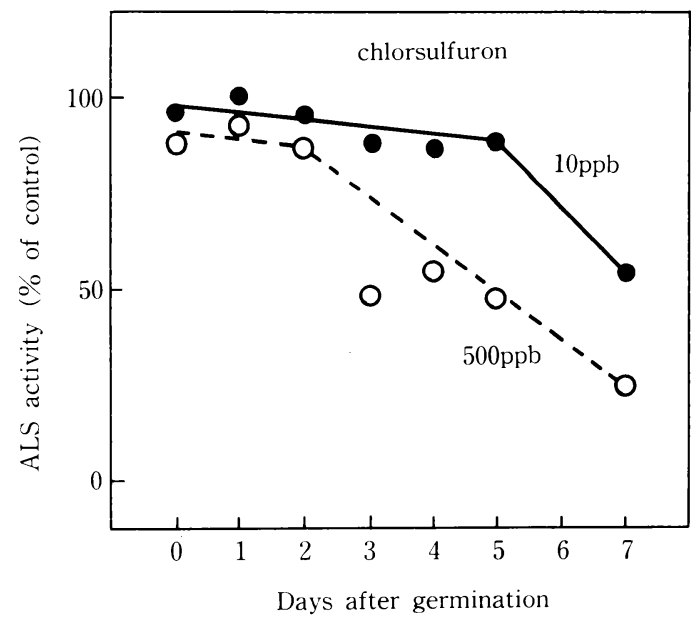

Fig. 2. Effects of chlorsulfuron on ALS activity of soybean cotyledon.

in a plastic case $(\mathrm{d} 5 \times \mathrm{w} 15 \times \mathrm{h} 10 \mathrm{~cm})$ and grown at $25^{\circ} \mathrm{C}$. The enzyme was extracted from cotyledon each day after germination. The inhibition of enzyme activity by chlorsulfuron was measured by the SP method, and results are shown in Fig. 2. Chlorsulfuron at $10 \mathrm{ppb}$ did not inhibit the ALS activity of soybean seedlings 5 days after germination, but inhibited by $40 \%$ the ALS activity at 7 days after germination. High concentration (500 ppb) of chlorsulfuron slightly inhibited the ALS activity at 3 days, but inhibited it by $50 \%$ at 5 days and $70 \%$ at 7 days after germination. The result that the ALS activity of soybean cotyledon at early growth stage was not inhibited by chlorsulfuron corresponded well with the chlorsulfuron insensitivity of soybean seedlings at this stage.

\section{Change of optimum $\mathrm{pH}$ of soybean ALS}

The reason the soybean cotyledon was not affected by chlorsulfuron was assumed to be the chlorsulfuron-insensitivity of ALS in the cotyledon. Therefore, the enzyme from the cotyledon was assayed by changing $\mathrm{pH}$ of the reaction mixture to examine whether the ALS had another optimum $\mathrm{pH}$ range. The absorbances at $525 \mathrm{~nm}$ of color complexes derived from the enzymatic product, either decarboxylated by acid or undecarboxylated, are

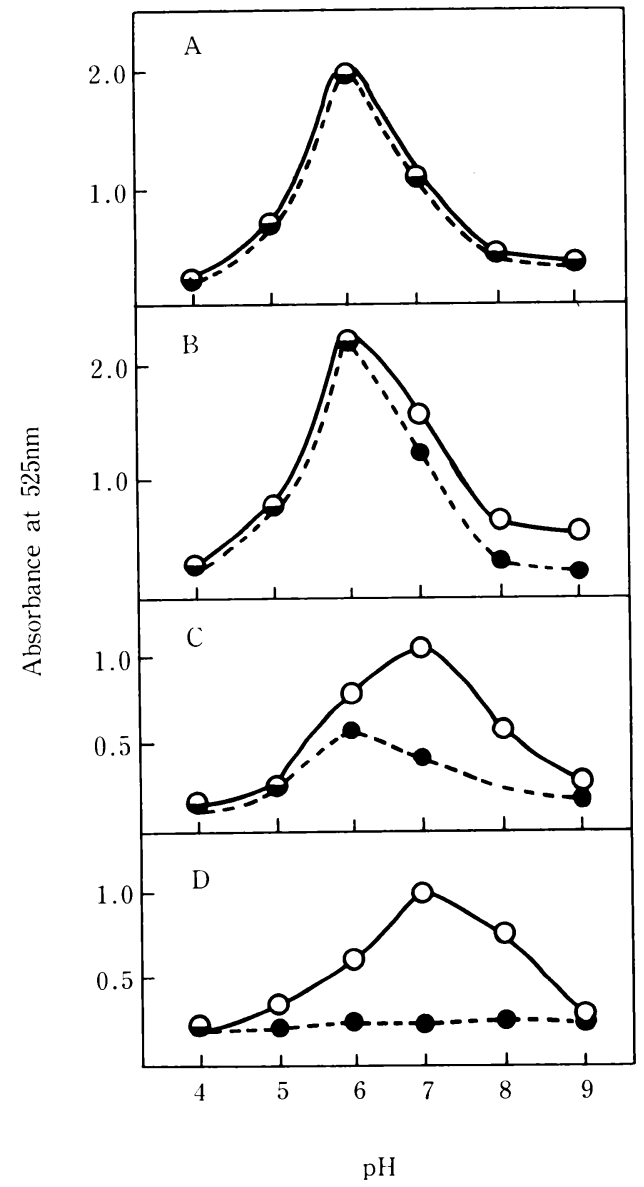

Fig. 3. Change of optimum $\mathrm{pH}$ of soybean cotyledon ALS assay after germination.

-O-: decarboxylated sample

…: undecarboxylated sample

A: 1 day, B: 3 day, C: 5 day, D: 7 day after germination.

shown in Fig. 3. At 1 day after germination, maximum peaks of both color complexes appeared on the acidic side ( $\mathrm{pH} \mathrm{6)}$ and these were reduced with the passage of time. The peak appearing at $\mathrm{pH} 6$ was considered as one derived from acetoin formed during the enzyme assay, while that appearing in the range of $\mathrm{pH}$ 7-8 from 5 days after germination was apparently derived from acetolactate because the absorbance of undecarboxylated sample was very low. These results showed that ALS did not exist in the cotyledon at the early days after germination of soybean but appeared after 5 days. 


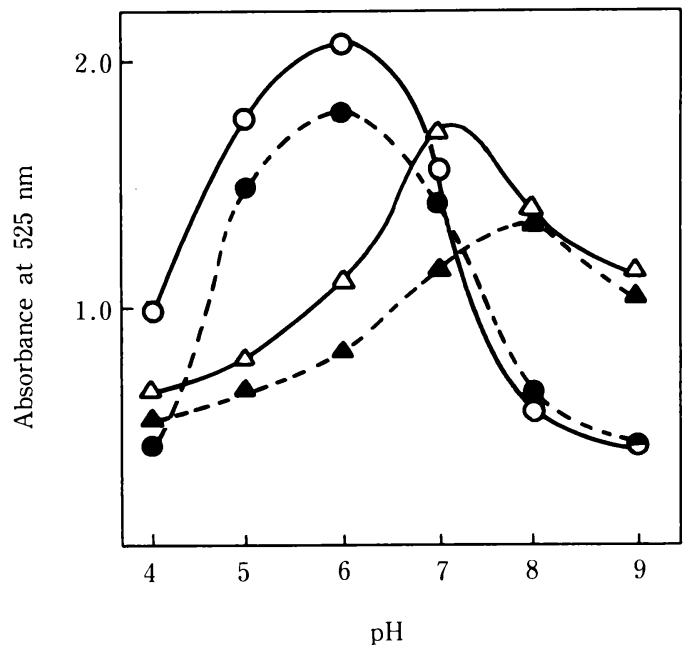

Fig. 4. Change of optimum $\mathrm{pH}$ of ALS assay of several plants.

-O-: leek,

$-\triangle-$ : wheat

The enzymes of rice and wheat were used at 7 days after germination. Absorbance indicated is without subtracting undecarboxylated value from decarboxylated value of the enzymatic product.

The absorbance of color complexes derived from decarboxylated enzymatic products after the enzym assay of wheat, rice, radish and leek at different $\mathrm{pH}$ are shown in Fig. 4. Maximum peaks in rice and wheat appeared at $\mathrm{pH} 7-8$, but those in radish and leek appeared at $\mathrm{pH} 6$, and their absorption profiles resembled that of soybean. From the maximum peak of absorbance at $525 \mathrm{~nm}$, the plant ALS seemingly can be classified into two types according to optimum $\mathrm{pH}$, one with the optimum $\mathrm{pH}$ on the alkaline side and the other with it on the acidic side. It seems that chlorsulfuron inhibits the former type which has acetolactate forming enzyme, but not the latter type which has acetoin forming enzyme.

\section{Determination of acetolactate formed} during ALS assay by gas chromatography

In the SP method for ALS assay by Westerfeld, the amounts of acetolactate are calculated as the sum of both acetoins, one formed in the enzyme reaction and one converted

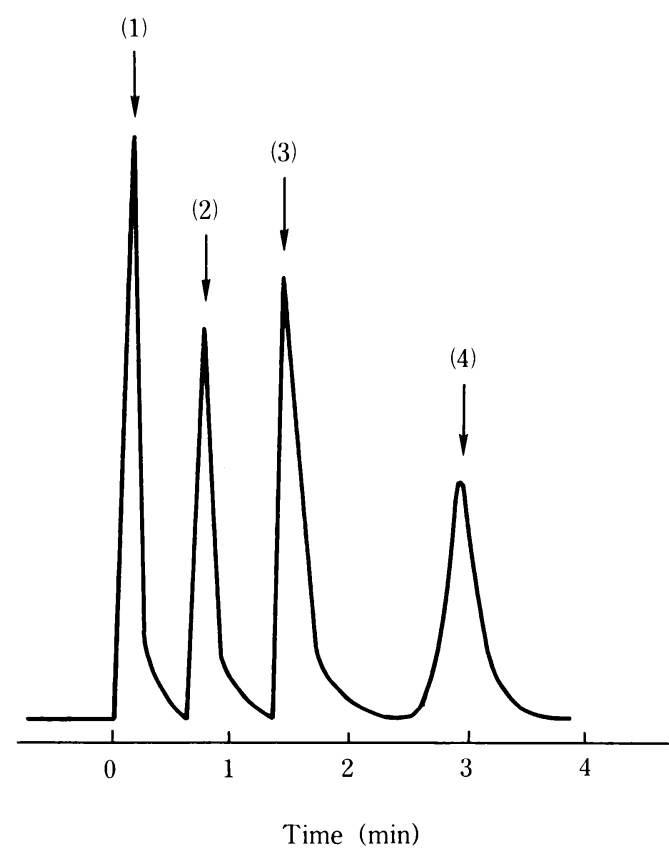

Fig. 5. Gas chromatogram of standard diketones. (1): solvent peak, (2): butanedione, (3): pentanedione, (4): heptanedione

from decarboxylation of acetolactate. Therefore, the possibility of measuring acetolactate formed in the ALS assay was examined by the GC method. A chromatogram of three authentic and separate diketones is shown in Fig. 5. An arrow-(1) was a solvent peak (methanol), and peak-(2), peak-(3) and peak(4) were identified as butanedione, pentanedione and heptanedione, respectively. The amounts of these diketones could be determined from the chromatographic peak area using heptanedione as an internal standard substance. Fig. 6 shows the chromatogram of the diketone derived from the enzymatic product in the ALS assay of wheat and soybean cotyledon when pyruvate was used as a substrate. The arrows in the figure indicate the peak of butanedione. A peak at the same retention time as that of butanedione appeared in the barley ALS assay without chlorsulfuron (1-a). The addition of $10 \mathrm{ppb}$ chlorsulfuron decreased the peak height by $85 \%(1-b)$ and $50 \mathrm{ppb}$ chlorsulfuron by $95 \%(1-\mathrm{c})$. In the 

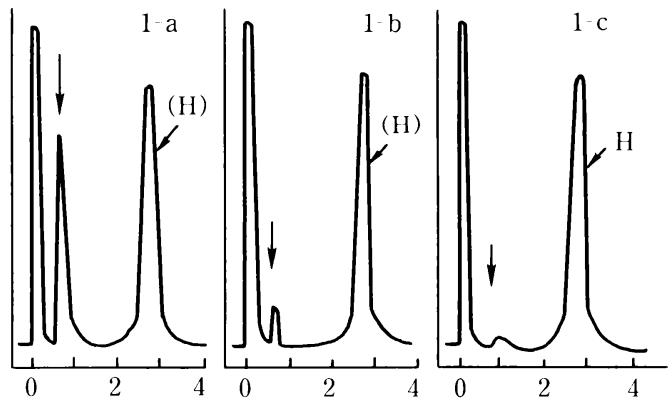

Time $(\mathrm{min})$
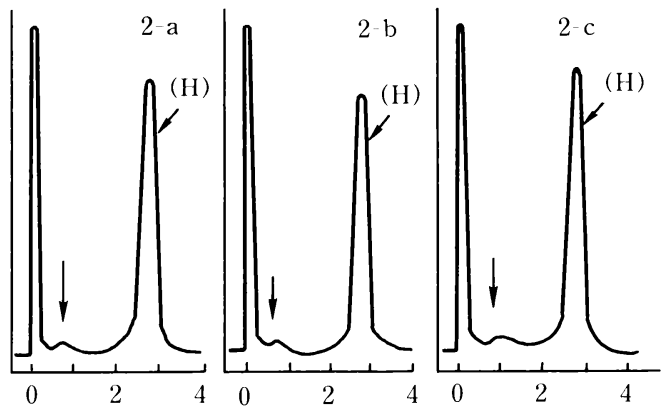

Time $(\mathrm{min})$

Fig. 6. Gas chromatograms of diketones drived from enzymatic products formed during ALS assay of barley (1) and soybean cotyledone (2).

The enzymes used were of barley 7 days and soybean 1 day after germination.

a: chlorsulfuron $0 \mathrm{ppb}, \mathrm{b}: 10 \mathrm{ppb}, \mathrm{c}: 50 \mathrm{ppb},(\mathrm{H})$ :

heptandione, arrows indicate butanedione.

soybean ALS assay, no peak corresponding to butanedione was detected in any cases for ALS assay $(2-a, b, c)$. The results that acetolactate formed during the barley ALS assay could be detected anb determined by the GC method, while no peaks were found in the soybean ALS assay indicated that acetolactate was not formed during the enzyme assay in soybean. The high absorbance at $525 \mathrm{~nm}$ detected by the procedure of Westerfeld must have been the result of acetoin formed during the enzyme assay.

Chlorsulfuron inhibition of 2-acetohydroxybutyrate formation in ALS assay

ALS catalyzes both the reaction producing acetolactate from two molecules of pyruvate in biosynthesis of valine and leucine, and that producing 2-acetohydroxybutyrate (AHB) from pyruvate and 2-ketobutyrate in biosynthesis of isoleucine. Acetolactate but not AHB could be measured by the SP method. Therefore, experiments were carried out to clarify whether or not AHB can be measured by the GC method, and also whether or not AHB formation during the ALS assay is inhibited by chlorsulfuron. After incubation of the enzyme assay solution containing the same moles of pyruvate and 2-ketobutyrate as substrates. the reaction mixture was oxidized by iron salt. The resultant diketone (pentenedione) was analyzed by GC. A peak at the same retention time of pentanedione was detected, which appeared to be derived from AHB formed during the ALS assay. On the basis of the above results, the effects of chlorsulfuron on AHB formation during the ALS assay were tested. Inhibition by chlorsulfuron of AHB formation in the barley ALS assay are shown in Fig. 7. The chlorsulfuron concentration which inhibited AHB formation by $50 \%\left(\mathrm{I}_{50}\right)$ was about $5 \mathrm{ppb}$. This value agreed with our prior result in which chlorsulfuron inhibited acetolactate formation in the enzyme assay of tobacco cell culture ALS ${ }^{12)}$.

Determination of acetolactate formed during ALS assay by high performance liquid chromatography

In the SP and GC methods, the quantitative

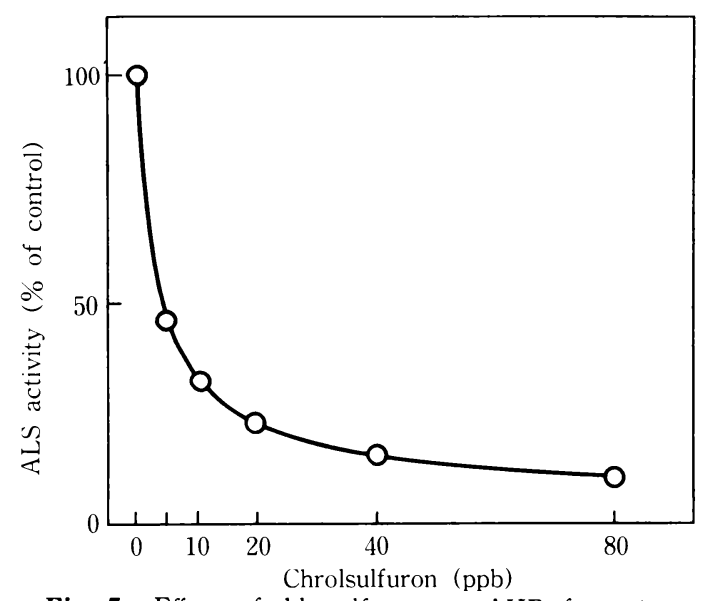

Fig. 7. Effects of chlorsulfuron on AHB formation from 2-ketolactate and pyruvate in barley ALS assay at 7 days after germination. 

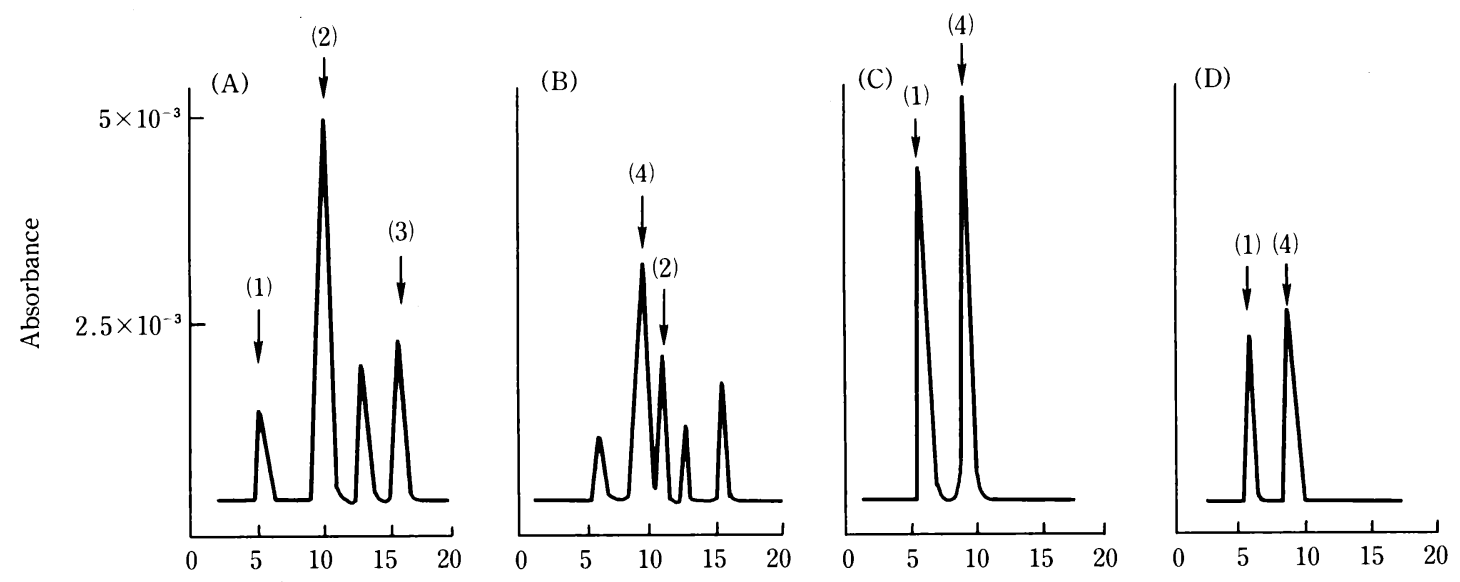

Time $(\mathrm{min})$

Fig. 8. Elution profiles of acetolactate, acetoin and pyruvate, and barley and soybean cotyledon ALS assay solution by HPLC.

(A): synthesized acetolactate solution, (B): A+pyruvate, (C): barley ALS assay solution, (D): soybean cotyledon ALS assay solution (1): solvent, (2): acetolactate, (3) acetoin, (4): pyruvate.

measurement of acetolactate was carried out after conversion into another compound. The direct measurement of acetolactate was attempted by HPLC. A chromatogram of the synthesized acetolactate solution loaded on HPLC is shown in Fig. 8-(A). Arrows-(1) indicate solvent peaks, and arrows-(2) at 10. $4 \mathrm{~min}$ of retention time $(\mathrm{Rt})$ indicate peaks of acetolactate identified, because of their ready conversion into acetoin after decarboxylation by acid. Arrow-(3) ( $\mathrm{Rt}=15.9 \mathrm{~min})$ show acetoin identified, because its $\mathrm{Rt}$ agreed with that of authentic acetoin. The peak at $\mathrm{R}=14$ min was an unknown compound formed in the synthesizing process. The chromatogram of the acetolactate solution mixed with pyruvate is shown in Fig. 8-(B). A peak of pyruvate indicated by an arrow-(4) appeared at $\mathrm{Rt}=9.1$, and acetolactate, acetoin and pyruvate could be clearly separated by HPLC.

Both the ALS assay solution of barley and soybean filtered through a membrane filter were loaded on HPLC: the elution profiles of both samples are shown in Figs. 8-(C) and 8-(D), respectively. A peak at the same $\mathrm{Rt}$ as that of pyruvate was detected in both ALS assay solutions, but no peaks at the same Rt as that of acetolactate could be detected.

These results revealed that HPLC could not detect acetolactate formed during the standard ALS assay. The absorbance of 80 pmoles of acetolactate in the ALS assay solution amounted to 1 at $525 \mathrm{~nm}$ by spectrophotometric measurement, whereas when the same moles of acetolactate were loaded on HPLC, the absorbance at $210 \mathrm{~nm}$ was 0.01 . It is judged that the concentration of acetolactate detectable by HPLC is $10-20$ pmoles, provided that $20 \mu \mathrm{l}$ of sample is injected into HPLC. Therefore, to detect acetolactate, a sample solution should be concentrated 5-6 fold.

\section{Discussion}

Chlorsulfuron did not inhibit germination of rice but inhibited its growth after germination. The herbicide's inhibition of wheat and barley was confirmed to be same as that of rice (data not shown). In soybean, chlorsulfuron inhibited neither germination nor growth during the 4 days after germination. The plants thus were classified into two groups 
according to their reaction to the herbicide after germination: chlorsulfuron-susceptible plants which have ALS with an optimum $\mathrm{pH}$ at 7-8, and chlorsulfuron-resistant plants which have no ALS but an acetoin forming enzyme with an optimum $\mathrm{pH}$ at 6 .

The observation that acetolactate was not detected in the soybean ALS assay solution appeared attributable to the existence of an enzyme which decomposes acetolactate formed during the assay. In order to confirm this assumption, authentic acetolactate instead of pyruvate was added to the ALS assay solution; the amounts of acetolactate, however, did not change at all compared to the control. This indicates that the formation of acetoin during the ALS assay of crude enzyme from soybean cotyledon is probably caused by the enzyme which directly catalyzes the reaction of acetoin formation from pyruvate.

Davies ${ }^{2)}$ reported that ripening pea seeds contained both acetolactate and acetoin-forming enzyme and that enzyme activities varied during the seed ripening process: in fully ripened seeds, the ALS activity decreased and the acetoin-forming enzyme activity increased. In legume plants, the acetoin-forming enzyme activity precedes the ALS activity in cotyledon as is true in fully matured seeds. It is likely that the high acetoin-forming activity is involved in regulating the supply of amino acids for storage protein synthesis.

Halpern and Umbarger ${ }^{8)}$ reported that two ALSs with optimum $\mathrm{pH}$ at 6 and 8 could be isolated from Aerobacter aerogenes, the former ALS being insensitive to valine inhibition, and not corresponding to amino acid synthesis but consuming pyruvate in overproduction. From such a viewpoint, it is likely that the acetoin-forming enzyme in legume plants consumes the excessive pyruvate accumulated in the seed and cotyledon just like microbial ALS with an optimum $\mathrm{pH}$ at 6 .

Muhitch $^{14)}$ isolated three ALSs from embryos in developing maize kernels using an ion exchange HPLC. One of these ALS, containing both ALS activity and pyruvate decarboxylase activity which catalyzes the formation of acetaldehyde and $\mathrm{CO}_{2}$ from pyruvate and has the ability to produce acetoin from two acetoaldehyde molecules, was not inhibited either by leucine and valine or by an imidazolinone herbicide imazapyr.

We earlier determined the presence of the acetolactate-forming enzyme in chick liver homogenate using the same method as for preparation of the plant $\mathrm{ALS}^{12)}$. This enzyme also was presumed to play a role in consuming pyruvate in chick liver, because it was insensitive to chlorsulfuron and valine. Certainly, further studies are necessary to clarify the nature of pyruvate metabolic interaction between the ALS and the acetoin-forming enzyme.

Acetolactate formed during the ALS assay could be determined by the GC method without any interference of acetoin formed simultaneously in the same assay solution. The GC method also made it possibile to determine AHB when 2-ketolactate was used as a substrate. For these reasons, the GC method is more useful in the study of the enzyme reaction mechanism and the interaction of herbicide and enzyme. The isolation and the quantitative determination of acetolactate could be done by HPLC when the authentic compound was used. The problem that acetolactate formed during the ALS assay was undetectable might be solved in the future by condensation of the solution.

The SP method is a simple one which dose not require much time for sample treatment and which can handle many samples simultaneously. In screening for plant ALS inhibitors, therefore, the acetolactate determination should be carried out by the SP method after decarboxylation of acetolactate. However in this case, the absorbance of undecarboxylated samples should be measured and subtracted from that of decarboxylated samples 
to obtain the net ALS activity, since the color complexes are derived from both acetoin and acetolactate, and only the latter is inhibited by chlorsulfuron. Compounds which inhibit acetolactate formation should thus be sought as a target in screening for plant ALS inhibitors. We are currently searching for plants which show high ALS activity but have acetoin-forming enzyme of low activity, and are screening the new ALS inhibitors.

Acknowledgements: The author would like to thank Yasushi Noguchi for his technical assistance in planning and conducting the experiments, and Professor Shooichi Matsunaka for a critical reading of the manuscript and insightful discussions.

\section{References}

1) Arfin, S.M. and D.A. Koziel 1973. Acetolactate synthase of Pseudomonas aeroginosa. I. Purification and allosteric properties. Biochim. Biophys. Acta. 321, 348-355.

2) Davies, M.E. 1964. Acetolactate and acetoin synthesis in ripening pea. Plant Physiol. 39, 53-59.

3) De Felice, M., C. Squires. and M. Levinthal 1978. A comparative study of the acetohydroxy acid synthase isoenzymes of Escherichia coli $\mathrm{K} 12$. $\mathrm{Bi}$ ochim. Biophys. Acta. 541, 9-17.

4) Durner, J. and P. Böger 1988. Acetolactate synthase from barley (Hordeum vulgare L.). Purification and partial characterization. Z. Naturforsch. 43 c, $850-856$

5) Gerwick, B.C., M.V. Subramanian and V.I. LoneyGallant 1990. Mechanism of action of the 1, 2, 4-triazole $\left[\begin{array}{ll}1,5 & \alpha-\end{array}\right]$ pyrimidines. Pestic. Sci. 29, 357-364.

6) Grimminger, $\mathrm{H}$ and H.E. Umberger 1979. Acetohydroxy acid synthase of Escherichia coli. Purification and properties. J. Bact. 137, 846-853.

7) Gollop, N., Z. Barak and D.M. Chipman 1987. A method for determination of the two possible products of acetohydroxy acid synthase. Anal. Biochem. 160, 323-331.

8) Halpern, Y.S. and H.E. Umbarger 1959 Evidence for two distinct enzyme systems forming acetolactate in Aerobacter aerogenes. J. Biol. Chem. 234, 3067-3071.

9) Kleschik, W.A., R.J. Ehr, B.C. Gerwick, W.T. Monte, N.R. Pearson, M.J. Costales and R.W. Meikle 1984. Novel substituted 1, 2, 4-triazolo1,5-pyrimidine-2-sulfonamides and methods of controlling undesired vegetation and suppressing the nitrification of ammonium nitrogen in soil. European Patent Application. 142152.

10) Krampitz, L.O 1948. Synthesis of $\alpha$-acetolactic acid. Arch. Biochem. Biophs. 17, 81-85.

11) La Rossa, R.A. and D.R. Smulski 1984. ilv B encoded acetolactate synthase is resistant to the the herbicide sulfometuron methyl. J. Bact. 160, 361374.

12) Matsunaka, S., N. Nakata, K. Hioki, Y. Noguchi and O. Yoshitake 1985. Comparison of the mode of action of chlorsulfuron between higher plants and animals. Proc. Brit. Crop. Conf. (weeds). Vol. 1. 139-145. BCPV-Publ., Croydon U.K.

13) Mifrin, B.B. 1969. Acetolactate synthetase from barley seedling. Phytochemistry. 8. 2271-2276.

14) Muhitch, M.J. 1988. Acetolactate synthase activity in developing maize (Zea mays L.) kernels. Plant Physiol. 86, 23-27.

15) Radhakrishnan, A.N. and E.E. Snell 1960. Biosy$\mathrm{n}$ thesis of valine and isoleucine. II. Formation of $\alpha$-acetolactate and $\alpha$-aceto- $\alpha$-hydroxybutyrate in $N$. crassa and E. coli. J. Biol. Chem. 235, 23162321.

16) Ray, T.B. 1984. Site of action of chlorsulfuroninhibition of valine and isoleucine biosynthesis in plant. Plant Physiol. 75, 827-831.

17) Shaner, D.L., P.C. Anderson and M.A. Muhitch 1984. Imidazolinones-potent inhibitor of acetohydroxy acid synthase. Plant Physiol. 76, 545-546.

18) Westerfeld, W.W. 1945. A colorimetric determination of blood acetoin. J. Biol. Chem. 161, 495-502.

19) Wixon, R.L. and M. Kanamori 1962. Enzymes for valine and isoleucine biosynthesis in spinach extract. Biochem. J. 83, 9 P. 
高等植物のクロルスルフロン感受性における アセトラクテートおよびアセトイン生成系の 関与

\section{中田 昌伸* \\ 摘要}

植物から抽出した粗醅素液に抢けるアセトラクテー 卜合成醅素活性は植物の種類によって，また生育段階 によっても変動し，アセトインの生成も認められてい る。本実験では, 数種植物の発芽後のアセトラクテー 卜合成酶素扰よびアセトイン合成醅素活性の変動と, これらの醅素に対する除草剤クロルスルフロンによる 阻害について検討し,さらにアセトラクテートの定量 法についても検討した。

1) 発芽後 4 日目までの緑豆，ダイズおよびアズキ

*神戸大学農学部

キーワード：アセトラクテート合成酵素，アセトラクテート， アセトイソ，クロルスルフロン
はクロルスルフロンによって生育阻害を受けなかった。 2）ダイズ種子および発芽後4 日目までの肧芽には アセトラクテート合成䤃素が存在しなかったが，アセ トイン合成醉素が存在していた。

3 ）至適 $\mathrm{pH}$ を6に持つアセトイン合成䣼素はクロ ルスルフロン阻害をうけないが, 至適 $\mathrm{pH}$ を 78 に 持つアセトラクテート合成酵素は阻害され，これを持 つ植物ほどクロルスルフロンによって強く生育が阻害 された。

4）ガスクロマトグラフィー分析によって醅素反応 で生成したアセトラクテート拉よびアセトハイドロキ シルブチレートの定量が可能であった。またダイズ種 子および肧芽から抽出した醅素にはアセトラクテート が生成されていないことが確認できた。

$5 ）$ 高速夜体クロマトグラフィー分析によって標品 のアセトラクテート，アセトイン拉よびピルビン酸を 用いると分離定量が可能であったが，醅素反応で生成 したアセトラクテートの検出は検出限界以下の濃度の ため不可能であった。

\section{書 評}

\section{「農業有用微生物」一その利用と展望}

梅谷献二・加藤 肇 共編

荃賢堂

1990年代は地球環境保全が人類の一つの大きな目標 になっており, 化学農薬, 化学肥料一辺倒の農業生産 技術体系から, 生態系に調和した新たな病虫害, 雑草 の制御技術，作物の生産管理技術へと転換が望まれて いる。このような新しい技術の一つとして，弱毒ウイ ルス, 天敵徽生物, 拮抗微生物, 窒素固定菌など有用 微生物の利用がある。本書はこのような有用微生物の 探索，バイオテクノロジーによる効率的な微生物の改 良や作出手法, 利用技術の開発, 問題点, さらに将来 展望にわたって幅広く有用微生物について整理してい る。

本書は農林水産省農業研究センターが組織した「作 物生産に拈ける有用微生物の探索と利用技術の開発に 関する研究会」で産学官の研究者が昭和 61 年から 3 力 年を費やし検討した結果を取りまとめたもので，その

\section{構成は}

第 1 章, 弱毒ウイルスによる作物ウイルス㾔の制御 第 2 章, 拮抗微生物による作物病害の制御 第 3 章，天敵微生物による作物害虫の制御 第 4 章, 微生物による雑草の制御 第 5 章，土壌有用微生物とその利用 からなっている。各章とも現時点での国内外の現状が 網羅され，第 4 章の雑草制御に係わるところでも， 1 . 微生物利用による雑草制御研究の現状, 2. 微生物の雑 草に対する病原性, 3. 雑草制御に打ける微生物代謝産 物の利用, 4. 雑草防除領域からみた土壤微生物, そし て5. 微生物による雑草制御の問題点と将来展望に整理 されており，今後これらの分野を研究し，利用開発を 進めようと考えている人にとって大変理解しやすい。 また，各章末には膨大な参考文献が掲載され，本書末 尾に事項索引とともに微生物名索引があることは読者 にとって大変好都合である。

新しい農業生産資材として有用微生物の期待は大き く, その効率的で安全な利用の可能性を求め, 本書が 多くの人々に読まれ活用されることを望みたい。

（農業環境技術研究所跉木隆之） 